\title{
Good Ukrainians vs Petliurites: The Ukrainian Revolution as a Soviet, Young-Adult Tale
}

\author{
Serhy Yekelchyk
}

University of Victoria

\begin{abstract}
Using as a case study Vladimir Beliaev's popular young-adult novel The Old Fortress and its two film adaptations, this article examines evolving Soviet representations of the Ukrainian Revolution. Its main focus is on the cultural construction of "Petliurites" as the "other" of Soviet Ukrainian identity. The article demonstrates that the Stalinist model of historical memory required a strong Ukrainian nationalist enemy in order to highlight the heroic deeds of the positive protagonists, who are encoded as pro-Russian or culturally Russian. By the 1970s, Soviet cinema turned to satirical depiction of the weak nationalist enemies, but the portrayal of Soviet Ukrainians also became more ambiguous, with few markers of ethnicity. Like Soviet Ukrainian culture in general, the book and the films presented Taras Shevchenko's legacy as the central field of contestation between the nationalist and Soviet versions of Ukrainian identity.
\end{abstract}

Keywords: Vladimir Beliaev, Cinema, Propaganda, Symon Petliura, Identity, “Other”

$\mathrm{B}^{\mathrm{s}}$

efore postwar Stalinist propaganda created the stock figure of a bloodthirsty nationalist Banderite, Soviet Ukrainian identity had a different "other" in the figure of a Petliurite, an anti-Soviet Ukrainian from the revolutionary period. ${ }^{1}$ The term "Petliurite" in both positive and negative sense became widespread already during the Ukrainian Revolution; Petliura's political opponents in the Ukrainian camp, such as General Oleksander Hrekov, decried the branding of the entire Ukrainian movement as "Petliurite" (Hrekov 173-190). The emergence of the term can be traced to Petliura's tenure as general secretary for military affairs in late 1917; it originally covered all Ukrainianized military units and their leaders, including even the future Hetman Pavlo Skoropands'kyi (Kalynchuk 2012). The informal self-designation of the Ukrainian military as Petliurites did not outlive the Ukrainian Revolution, but it survived until the 1940 s as a Soviet term of opprobrium for Ukrainian "nationalists." In

\footnotetext{
1 "Petliurite" and "Banderite" refer, respectively, to the followers of Symon Petliura, the minister of war and later head of the Ukrainian People's Republic (1917-20) and Stepan Bandera, the leader of the Bandera faction of the Organization of Ukrainian Nationalists from 1940 to his assassination in 1959.
} 
everyday usage, "Petliurites" replaced the earlier tsarist labeling of all patriotic Ukrainians as "Mazepists" (Kappeler 2003). Only after the war would these connotations be transferred to the term "Banderites." Stalin continued referring to anti-Soviet Ukrainians as "Petliurites" long after Petliura's assassination and the emergence of the Organization of Ukrainian Nationalists (OUN) as the new, leading militant force among Ukrainians abroad. On the eve of the Holodomor he wrote that the Communist Party of Ukraine was full of "conscious and unwitting Petliurites" (Stalin, "Pis'mo" 274). Even when criticizing in January 1944 Oleksandr Dovzhenko's film script "Ukraine in Flames," Stalin spoke of "Petliurites and other Ukrainian nationalists," rather than "Banderites," as "vile traitors of the Motherland," fighting together with the Germans (Stalin, "Ob antileninskikh" 694). In Soviet mass culture, much as in the Russian state media today, both clichés referred to patriotic Ukrainians in general rather than to the actual soldiers of the Ukrainian People's Republic or fighters of the 1940s nationalist underground. Any person suspected of disloyalty to the official version of Soviet Ukrainian identity—which after the 1930s was increasingly defined as pro-Russian - could be branded a "Petliurite" or "Banderite."

Understanding how these notions gained mass currency in Soviet and Russian popular culture requires an inquiry into the cultural construction of a Ukrainian nationalist as the enemy "other" of a good Soviet Ukrainian. This article will examine the portrayal of "Petliurites" and their opponents in several versions of a popular Soviet youth adventure story that takes place in Ukraine: Vladimir Beliaev's trilogy The Old Fortress (Staraia krepost', 1937-50) and its two extant cinematic adaptations. This work can serve as a productive case study because its various incarnations reflect evolving Soviet representations of the Ukrainian Revolution from the 1930s to the 1970s, as well as the influence of changing aesthetic concepts and mass-culture paradigms.

In Soviet Ukrainian historical writing and culture of the 1920s, the portrayal of Petliurites was ambiguous. Historians wrote, albeit with reservations, of the "revolutionary character" of the Ukrainian People's Republic, while the plays of Mykola Kulish portrayed anti-Soviet nationalists as tormented figures rather than clear-cut "others." Dovzhenko's Arsenal (1929) was a good fit for the contemporary Stalinist

\footnotetext{
2 In Soviet Ukraine during the 1920s, the construction of socialism and Ukrainian nation-building remained compatible, even interrelated projects. By the decade's end, however, Stalinist ideological tenets cemented the black-and-white depiction of the Revolution, resulting in the official critique of Kulish's Sonata Pathétique (1929), in which a nameless main hero is torn between the party ideology and Ukrainian patriotism.
} 
turn in Soviet historical scholarship in that it depicted nationalists unambiguously as enemies. When the film came out, Dovzhenko apparently started becoming estranged from the Ukrainian cultural elites, which had ostracized him as a "traitor" (Trymbach 248-49). Meanwhile, the Ukrainian nationalists in Arsenal are weak and irrelevant, and their visual depiction smacks of caricature. In contrast, the developing conventions of Stalinist culture included the archetype of a strong adversary as part of a binary opposition between the powerful hero and the dangerous enemy. As Katerina Clark has argued, the villain in Stalinist culture served as "a symbolic victim who must be purged in order for the microcosm to be purified." Moreover, the tale of villainy is crucial to the plot of Socialist Realist novels and films as part of the main hero's "initiation ritual" (Clark 186-87). Both these considerations dictate the portrayal of a strong enemy who can be overcome only with difficulty. It is productive to approach The Old Fortress with this cultural context in mind.

Very few works of Soviet literature, let alone Soviet children's literature, can boast of three film adaptations. Beliaev's trilogy The Old Fortress is one such rare example. This article will examine his three novels and the two surviving eponymous films for clues to the work's appeal among the figures of the Soviet Ukrainian cinema industry. My argument is that Beliaev conveniently framed the Ukrainian Revolution and the subsequent Soviet repressions in Ukraine as a children's game, an adventure story with clearly defined "us" and "them." He also picked the "right" enemy, Ukrainian nationalists, a choice that would ensure the work's perennial topicality for Soviet authorities. However, the plot lines and visual tropes in the two extant film versions differed markedly, reflecting the changing Soviet concepts of Ukrainian identity and enemies of the state. This evolution ran parallel to and shared many features with what Joshua First describes as the transition from a Stalinist folkloric mode of national representation to ethnographic "authenticity" in Ukrainian poetic cinema of the 1960s and, finally, to the imposition of Soviet supranational topics in the 1970s (First 13-17). In the portrayal of Petliurites and Soviet Ukrainians, the Stalinist trope of a strong villain, who must be eliminated in order to restore symbolic order, is replaced first by a more ambiguous poetic depiction of wartime childhood and then, by a late Soviet depiction of Ukrainian folk tradition as a marker of nationalism. The positive heroes appear more ambivalent and less grounded in Ukrainian identity, while the adventure element is replaced by a focus on production. 


\section{THE NOVEL}

The first novel in Beliaev's trilogy, The Old Fortress (1937), occupied pride of place in Soviet children's literature. Like Arkadii Gaidar's School (Shkola, 1930) and Valentin Kataev's A White Sail Gleams (Beleet parus odinokii, 1936), it is a juvenile adventure book set in revolutionary times. All these bestsellers combined to some degree the themes of coming of age, acquiring socialist consciousness, and uncovering a mystery. However, Beliaev's book stood out among the works of early Soviet children's literature in that it borrowed more openly from Western juvenile literature, which was still condemned officially in the USSR as an apolitical literary genre. The 1937 novel featured as the main setting an old, abandoned castle with mysterious underground passages. Other plot elements also sounded familiar to literary critics who remembered pre-revolutionary translations of Western children's literature. At the time, Beliaev was particularly criticized for imitating Mark Twain's The Adventures of Tom Sawyer (Razumnevich 18). There are indeed quite a few similarities in the plot, for example, discoveries that the children make in the underground passage, or cave, the night-time oath sworn by the heroes, and even the main character, who lives with his aunt. These may have been the very components that ensured the novel's success.

By the early 1980s the original novel and the trilogy were issued in over thirty Russian-language editions, not counting numerous translations, including repeated editions of the Ukrainian version (Razumnevich 4-5). The print runs were also impressive: The two editions I consulted, the 1982 one by the Moscow publishing house Molodaia gvardiia and the 1984 one by the Kyiv publisher Radians'ka shkola, also in Russian, list their total print runs as 300,000 copies each. Such figures suggest more than the state's interest in promoting Beliaev's novel; indeed, both scholars and memoirists note the popularity of this Soviet adventure novel for young people. After the war, Anatoly Rybakov followed in Beliaev's footsteps by employing plot devices from adventure stories, a staple of Western juvenile writing, in his highly popular novels Dirk (1948) and Bronze Bird (1956) (Kelly 555). Even the future Ukrainian dissident and modernist theater director Les' Taniuk was fascinated with Beliaev's book in his youth (Taniuk 1: 266).

The Old Fortress stood out in another respect. Alone among the most popular works of early Soviet children's literature, it focused on denouncing Ukrainian nationalists as the main enemy. The main villains of Beliaev's novel, which is set during the Civil War in the western Ukrainian city of Kamianets-Podilsky, are conscientious, ideologically-driven "Petliurites." Beliaev's own background predetermined such a focus. Although he wrote in Russian, he grew up in Kamianets-Podilsky and, just like his heroes, was 
a schoolboy at the time when this city was the temporary capital of the Ukrainian People's Republic in 1919. As a technical school student in the early 1920s, he served as a reservist in the Special Purpose Units (Chasti osobogo naznacheniia), which helped enforce order in the border region, but mostly alleviated Soviet paranoia about potential "Petliurite" incursions from Poland. After World War II, as he was writing the third novel of his series, Beliaev worked as a Soviet journalist in Galicia, at the time the bulwark of the Ukrainian nationalist insurgency. After his appointment as head of the Pravda office in Lviv, he published a series of political pamphlets exposing the "Ukrainian bourgeois nationalists," such as, Under Alien Banners (Pid chuzhymy praporamy, 1958), Birds of the Night (Nochnye ptitsy, 1965), A Recipe for Poison (Formula otruty, 1971), I Accuse (Ia zvynuvachuiu, 1978), etc. (Razumnevich 119-26).

An ethnic Russian and a devoted communist, Beliaev grew up in the region where the Ukrainian People's Republic held out the longest, and for much of his adult life he worked in another region, where the Soviets saw Ukrainian insurgency and "nationalist deviations" as the main threat to their authority. After the war Beliaev emerged as a leading Soviet literary figure speaking out against Ukrainian nationalism. Thus, it is no surprise that similar motifs are present in his literary works, including those from an earlier period. Beliaev's magnum opus, the trilogy The Old Fortress, is no exception in that the main enemies in all three novels are Ukrainian nationalists. The first novel, The Old Fortress (1937), features Symon Petliura and his army, as well as Ukrainian boy scouts (Plastuny). Former "Petliurites" and boy scouts reappear as spies and saboteurs in the sequels set in the 1920s: The Haunted House (Dom s privideniiami, 1941) and A City by the Sea (Gorod u moria, 1950). In 1946 Beliaev wrote to the Moscow publisher Molodaia gvardiia, noting that a new edition of the first two novels was politically important in view of the "threat from burgeoning Ukrainian nationalism" in the western regions (Fateev 99). In the 1967 epilogue to the trilogy, "Twenty Years Later" (Dvadtsat' let spustia), readers learn that the head of the Ukrainian scout movement in Kamianets-Podilsky during the Ukrainian Revolution became a Nazi collaborator in World War II (Beliaev, 555). Beliaev thus established the Ukrainian nationalists as the permanent enemy, the constant "other" of Soviet Ukrainian identity.

In The Old Fortress Beliaev paints an extremely unsympathetic portrait of the Ukrainian leader Symon Petliura, who is shown attending a school concert. The narrator diminishes Petliura as a statesman by depicting him as a familiar small-town type:

Dressed in a blue military jacket buttoned all the way up, Petliura was sitting in a theater box on a plush chair, with one leg over the other. In his hand he 
held his military cap à la Kerensky, with a gold trident on the band. Petliura's hair was combed over very smoothly to the left; he must have greased it with burdock oil.

I thought I had seen Petliura somewhere, but I could not remember at the time, and it only came back to me later. The same type of sleek, haughty man was painted on the sun-discoloured tin-foil sign of our Zareche barber, Novizhen. Petliura was constantly looking around, and once he even stooped discreetly to look under the soft spring chair on which he was sitting. Seeing that there was no one under the chair, he quieted down and started gazing at the portraits of his ministers (Beliaev, Staraia krepost' 27$){ }^{3}$

Beliaev also presents the government forces of the Directory of the Ukrainian People's Republic as oppressive and lacking all popular support. The "Petliurites" carry out searches, beatings, and executions. Above all, they never actually defeat the Reds, who withdraw on their own. As soon as the Reds come back, Petliura's troops loot stores and make their escape.

Of course, Beliaev's young protagonists - three boys and a girl: Vasilii Mandzhura, Pet'ka Maremukha, Yuzik Starodomsky, and Galia Kushnir-do not fight directly against Petliura's army. ${ }^{4}$ The immediate objects of their hatred and pranks are the high school principal Prokopovich (a real historical person) and the "Petliurite priest" Kiianitsa, the religion and history instructor, who is portrayed as an ignorant drunk. ${ }^{5}$ The main protagonists engage in fisticuffs with their peers from Plast, the Ukrainian scout organization, who are consistently referred to in the novel as "Boy Scouts" rather than by its Ukrainian name, Plast. Beliaev skilfully develops the character of their leader, Kot'ka Grigorenko, as the main antagonist. Kot'ka is a schoolyard bully and Vasilii's rival for Galia's attention, but he is also the son of a wealthy doctor who sympathizes with the Petliura regime. The transition from classmates to enemies is marked by a hide-and-seek

\footnotetext{
3 The Kamianets barber, Yankel Novizhen, is a real historical person, who was arrested as an enemy of the people in 1937 (Natsional'nyi).

${ }^{4}$ Here and elsewhere I use the Russian spellings of the characters' names as they appear in the novel and the films, although the reader assumes that Vasilii, Pet'ka, and Galia are Ukrainian. Vasily is often called Vasil', which is the awkwardly Russified version of the Ukrainian name Vasyl'. Yuzik is explicitly referred to in the novel as a Pole.

5 Viacheslav Prokopovych (1881-1942) served the Ukrainian People's Republic in various capacities: he was the minister of education in 1918 and premier from June to November 1920. Kiianitsa is an invented character, but for the cognoscenti Beliaev connects him to the Ukrainian Autocephalous Orthodox Church by mentioning in passing that he officiated at the marriage of Petliura's aide-de-camp, Stepan Skrypnyk, the future Patriarch Mstyslav of the UAOC.
} 
game in the fortress, which leads to a fistfight that is replayed later in the novel, when the young friends lead the attack on the Plast camp in the forest and capture their blue-and-yellow flag. Of course, this game-like fight replicates symbolically the Red Army's impending victory over the Petliura troops.

If Ukrainian nationalists are "bad" Ukrainians, the "good" Ukrainians in the novel are the former history teacher Valerian Lazarev and the Donbas miner Timofei Sergushin. Lazarev tells the boys stories about the fortress and takes them to explore the underground passage, where they find the skeleton of a long-dead prisoner. Of course, Lazarev introduces them to the class interpretation of history, in which the fortress is remembered primarily as a place where the legendary peasant outlaw Ustym Karmaliuk (1787-1835), the Robin Hood of Ukrainian folklore, was imprisoned and from which he escaped. Characteristically, both of these positive adult role models have Russian-sounding surnames and speak Russian. Yet, at least in the case of Lazarev, the text implies his Ukrainian ethnic identity. For example, Lazarev feels the need to explain his preference for the Russian language. He blames his poor command of Ukrainian on the tsarist prohibitions against this language, but he also says that the language issue is secondary to him, and "one should not decide the fate of Ukraine separately from that of all the peoples of Russia" (Beliaev, Staraia krepost' 19). In the sequel, he is explicitly opposed to the "Galician" Zenon Pecheritsa, who in the mid-1920s enforces the policy of Ukrainization in the district and is soon exposed as an enemy of the people.

Unlike Lazarev, Sergushin does not have much influence on the young heroes. The head of the revolutionary tribunal in the city under the Reds, he falls ill just before their retreat and has to seek refuge in private houses. Vasilii only meets him briefly on the night of the Reds' retreat, when the ailing Sergushin shows him how to make animal shadows with his hands. Later, the boys accidentally witness his execution in the fortress and afterwards tend his grave. Sergushin is a symbol of the Red cause, more so in death than in life, for it is on his grave that the young heroes swear an oath of friendship and revenge against the Petliurites. The commissar's ethnic identity is never clarified. A former Donbas miner, he could be either a Russian or a Russophone Ukrainian, but he does come from the region that would become part of Soviet Ukraine. It is significant that Beliaev felt the need to create such a character with an amorphous but pro-Russian identity as an influence on the boys. The writer confessed that he invented the character of Sergushin retroactively, after the first ten chapters were completed, and only after the publisher asked him to define this figure better (Beliaev, "Nachalo" 171-72). At the end of the novel the Reds build a real monument on Sergushin's grave with the inscription "To a fighter for 
Soviet Ukraine," thus affirming the commissar's Soviet Ukrainian identity regardless of his ethnicity. Meanwhile, the young protagonists' statements to the Cheka help implicate Kot'ka's father, who was a medical witness at the execution.

One of the most memorable episodes in the novel-the scandal at the school concert-signals to readers that the book's main conflict is really between the nationalist and Soviet versions of Ukrainian identity. In order to include this important scene, Beliaev had to merge the two arrivals of the Ukrainian army in the city. The text begins with the Reds abandoning Kamianets-Podilsky and the Petliurites moving in from across the river. However, this sequence of events happened three times: on 3 June 1919, 1 May 1920, and 19 September 1920 (Iurkova 47 and 52-53). On the last two dates, Petliura and his troops were allied with the Poles. In Beliaev's novel one of the Bolshevik characters says that the retreating Red Army is marching to protect the Donbas from the White troops of General Anton Denikin, which would indicate 1919. At the beginning of the novel, when the three young boys are transferred to the newly established Ukrainian secondary school, the reference is also to 1919. At the same time Beliaev stresses repeatedly that Petliura's troops arrived together with their Polish allies, which would suggest 1920 . Obviously, the writer combined two or three different events into one in order to present the Ukrainian government as a Polish puppet, thereby contributing to the "othering" of non-Soviet Ukrainian identity. This change also set the stage for the incident at the concert.

When Vasilii is asked to recite some poetry by the Ukrainian poets Stepan Rudans'kyi and Taras Shevchenko at the school concert in honor of Petliura, he innocently selects Shevchenko's poem "When We Were Cossacks" ("Poliakam." The first line reads: "Shche iak buly my kozakamy"). In the presence of Petliura and the Polish officers as well as a Polish priest, he reads the national bard's lines about Catholic priests destroying the ancient brotherhood of Ukrainians and Poles. The poem causes a scandal. A Polish officer demands the removal of Shevchenko's portrait from the hall. Petliura himself orders that the picture be taken down, and the Ukrainian Boy Scouts readily accomplish this task. Placed in detention, Vasilii imagines himself as Shevchenko in a tsarist prison and reads the poem to the end. He even hears in his mind the poet's encouragement, "Don't be sad, Vasil"' (Beliaev 33-34). Now that Petliura and his followers have rejected the father of the nation, they have proven themselves to be impostors. Instead, the bard himself appears to be on the side of Vasilii and his friends, the pupils of Lazarev and Sergushin.

The young heroes, who are about eleven years old in the first novel, turn fourteen in the second. They are now students at a technical school. 
They are eighteen years old in the third novel, in which the narrator follows two of them to a large factory in the port city of Mariupol. They, and Vasilii in particular as the author's alter ego, provide continuity in the trilogy. The youngsters' mentors change, as do the main villains. In The Haunted House a Komsomol activist named Nikita Kolomeets takes Vasilii under his wing, while the assortment of the enemies includes Ukrainian nationalists and Polish saboteurs sent from across the border, as well as local Ukrainian "gangs" and the boys' old classmate Kot'ka Grigorenko, who is trying to worm his way into the Komsomol. In the opening chapters of $A$ City by the Sea a new villain appears in the person of the new head of the school district, who demands the immediate switch to Ukrainian-language instruction in Kamianets-Podilsky. He is Dr. Zenon Pecheritsa, "a short, mustachioed man wearing riding-breeches, tall, yellow boots, and a simple linen shirt with embroidery across the chest. He had a remarkable mustache-red, fluffy, and droopy" (Beliaev, Staraia krepost' 322). A native of Galicia and a former officer in the Ukrainian Sich Riflemen who stayed in Soviet Ukraine after the Civil War, Pecheritsa is, of course, a nationalist ringleader. ${ }^{6} \mathrm{He}$ is awaiting a secret visitor from abroad, the former Petliurite otaman Kozyr-Zirka, who is now a British agent tasked with blowing up the ammunition depot in town. ${ }^{7}$ After the youngsters help the GPU to foil this plot, the reader loses sight of Yuzik, Galia, and Kot'ka, while Vasilii and Pet'ka become workers in Mariupil, where they uncover a conspiracy to dynamite the factory on a signal to be given by Kozyr-Zirka. Since the latter and Pecheritsia have already been apprehended, all that remains to be done is to arrest the factory's worst idler and a dance teacher (a former countess) in the town, who have been identified as foreign agents. A worthy rival of the fantastic conspiracies that NKVD investigators were inventing in 1937, Beliaev's storyline ends in 1926 with Vasilii's visit to Kamianets-Podilsky, now safely protected from foreign incursions by a Red cavalry regiment.

\footnotetext{
${ }^{6}$ Galicians were indeed among the first targets of Stalinist terror in the Ukrainian republic. See Rubl'ov 332-87.

${ }^{7}$ Oleksii Kozyr-Zirka was a Ukrainian warlord (otaman) of the revolutionary period, whose troops carried out a Jewish pogrom in the town of Ovruch in December 1918. In 1919 the Ukrainian authorities put him on trial in Kamianets-Podilsky, but he escaped after the city was captured briefly by the Whites. It has been suggested that he served as the prototype of Otaman Kozyr-Leshko in Mikhail Bulgakov's White Guard. According to some sources, in the early 1920s Kozyr-Zirka served in the Cheka; his later fate is unknown. See Tynchenko, Ofitsers'kyi korpus 1: 206-7 and Tinchenko, "Belaia gvardiia" 52-53.
} 


\section{THE MoviE}

In 1952 Beliaev was awarded the Stalin Prize for the first edition of all three novels as a trilogy in one volume under the joint title The Old Fortress. The film industry became interested in his magnum opus early on, almost immediately after the original The Old Fortress was published under a different title in a literary journal in 1936 and under the present one as a separate book the next year. The Odesa Film Studio produced a film adaptation in 1938 with Miron Bilinsky as the director and Beliaev himself as a screenwriter. However, the film was not released. During his brief tenure at the helm of the Soviet film industry in 1938, the long-time NKVD official Semen Dukelsky apparently ordered it destroyed, most likely because Beliaev had been arrested briefly as an enemy of the people (Galias). As far as I could ascertain, neither any visual material nor the studio production file for this film have survived.

Soon after Beliaev received the Stalin Prize, however, the Kyiv Film Studio expressed an interest in adapting the entire trilogy for the screen. Beliaev again offered to write the script, this time joining forces with the experienced screenwriter Mikhail Bleiman. The novelist's participation made possible the introduction of radical changes to the storyline, as well as cuts that the trilogy's transformation into a ninety-minute film necessitated. In the end, Beliaev and Bleiman had good reason to claim that their script was essentially a new work rather than a simple film adaptation of the novel, which resulted in a larger honorarium. ${ }^{8}$ The co-authors adapted the plot to suit the political expectations and artistic sensibilities of mature Stalinism. The completed film, Restless Youth (or Trevozhnaia molodost' in Russian, 1954), remains an archetypal example of a Stalinist historical-revolutionary movie for young adults, even though it was released after Stalin's death.

Already in the first synopsis of the script one can see the influences of World War II and its representations in Soviet cinema. Kamianets-Podilsky is characterized as "a town humiliated by the Petliurite occupation, tormented and terrorized." Petliura's troops "brutally establish their order" and are assisted in this by the "young fascist" Kot'ka Grigorenko (TsDAMLM, 670/1/488, ark. 1-2). While preserving the old fortress's centrality to the plot, the scriptwriters wanted the young friends to discover at the end of their adventure that the Bolshevik underground had stored weapons and the printing press used for producing leaflets in its

\footnotetext{
8 The studio increased the co-authors' total honorarium from 50,000 rubles to 60,000 . See Tsentral'nyi derzhavnyi arkhiv-muzei literatury i mystetstva Ukrainy (hereafter cited as TsDAMLM), f. 670, op. 1, spr. 556, ark. 9.
} 
underground passages (TsDAMLM, 670/1/488, ark. 3). Even though the latter detail is not in the film, its plot and the visual narrative are still highly influenced by World War II. The film opens with a battle for KamianetsPodilsky, which is not based either on historical fact or Beliaev's novel. Red soldiers are firing a machine-gun from the trenches, and heavy explosions are heard in the background; a Red officer works a field telephone, trying to reach the city's Revolutionary Committee. The pouring rain and the heroic melody of symphonic music playing in the background reinforce the impression of a courageous defense.

Petliura and the school concert are not included in the film, which features instead the violent entrance of the Ukrainian army. The soldiers smash store windows and whip the city dwellers, who are shown running for their lives. The scene is suggestive of a violent Jewish pogrom, a familiar feature of small-town life in Right-Bank Ukraine during the chaotic events of 1919, except that no such pogrom took place in Kamianets-Podilsky after Ukrainian troops entered the city in June 1919. In fact, even Beliaev does not describe such a pogrom in the novel, although he mentions Jewish pogroms in other towns. ${ }^{9}$ The bourgeois-looking public offers the Petliurites the traditional Ukrainian welcome of bread and salt, but all the schoolchildren refuse to yell "hurrah" to Petliura when a huge, drunk captain of the Ukrainian army tries to establish a new order at the school. Far from the later Soviet comedic stereotype of a Civil-War otaman, he is frightening, ideologically motivated, and ignorant. In a visually suggestive sequence he enquires about the picture of a banded anteater hanging on one wall; with regard to Pushkin's portrait on another wall, he asks if the person portrayed is a Jew. Then the captain accuses the schoolchildren of liking Jews and Russians, and crushes the picture of the banded anteater with his boots. ${ }^{10}$ Standing next to the wall of the classroom, coldly determined to resist the new order, the young heroes look just like the protagonists of The Young Guard (Molodaia gvardiia, 1948), a classic Stalinist film mythologizing youth resistance to the Nazi regime.

Indeed, the parallels with The Young Guard do not end there. Stalinist ideologists had criticized the first version of Aleksandr Fadeev's novel The Young Guard for not emphasizing the party's guidance of the young resistance fighters. Both the writer and the filmmakers worked hard to introduce this theme in the second edition, as well as in the film, and all

\footnotetext{
9 No pogrom in Kamianets-Podilsky is mentioned in the authoritative work by Henry Abramson. See Abramson.

10 In the novel, the image of the anteater is used simply to ridicule the Ukrainian government: A school warden replaces this picture with one of the Ukrainian ministers because he runs out of frames for all the portraits.
} 
other Soviet culture producers took notice. ${ }^{11}$ The storyline of The Old Fortress also underwent transformations along the same lines. As officials at the Ukrainian SSR's Ministry of Culture noted when they approved the script, Beliaev and Bleiman "developed more fully the characters of the communists Kolomeets and Sergushin and showed how each of them influenced the shaping of Vasilii Mandzhura's personality" (TsDAMLM, $670 / 1 / 488$, ark. 13). In the film, Vasilii gets to know Sergushin quite well and even receives an assignment from him to gather intelligence in the town. Because Vasilii's father is not portrayed in the film (he was killed in World War I), Sergushin is also established as a symbolic father. He tells the boy that he too has a son named Vasilii, whom he has not seen in many years. The commissar, played by the star of Soviet war films Nikolai Kriuchkov, even finds the time to sing a song for Vasilii. Somewhat incongruously, however, it is a miner's song, whereas in the film Sergushin is no longer a miner from the Donbas but a factory worker from St. Petersburg-an archetypal "elder Russian brother" of Stalinist historical mythology.

The unnamed "secretary of the Central Committee" in Kharkiv takes over this role later in the film, when Vasilii travels to the Soviet Ukrainian capital to foil Pecheritsa's evil plans to expel Russian-speaking instructors and close down the technical college. Played by another Soviet star, Vasilii Babochkin of Chapayev fame, the secretary wears an embroidered Ukrainian shirt with a formal black jacket as a visual signal of a "true" Ukrainian authority figure. He also gives Vasilii advice about his love life, much like Stalin does in his symbolic role as the father of the Soviet family in Mikhail Chiaureli's The Fall of Berlin (Padenie Berlina, 1949) (Kaganovsky 147-153). The character of Kolomeets also underwent a telling transformation. While he remains Vasilii's mentor, he is now a GPU/NKVD officer hunting enemies of the people.

Another screenwriting achievement that was praised by the Ministry of Culture was the "more truthful" depiction of enemies, particularly the portrayal of Pecheritsa as a "powerful and dangerous enemy," a ringleader "uniting all the others" (TsDAMLM, 670/1/488, ark. 13). Interestingly, this was what the studio representatives had asked the scriptwriters to do. Concerned about the first draft "giving a weak treatment to the topic of fighting against such a dangerous enemy as Ukrainian nationalism," studio officials demanded that they portray a "united camp of enemies" and its head, Pecheritsa, as a stronger villain (TsDAMLM, 670/1/488, ark. 36). As a result, Pecheritsa appears in the film from the very beginning. He is the one

${ }^{11}$ For a treatment of the Young Guard myth in English, see Fürst, chap. 4. 
who shoots Sergushin in the opening scene while still dressed as a spy or a saboteur wearing civilian clothing. Then he reappears in Ukrainian military uniform as a security officer serving under Petliura. When Kot'ka Grigorenko betrays the hiding place of the wounded Sergushin, Pecheritsa praises his "good deed" and "serene eyes," expressions that a Nazi might use in a Soviet film. (There is nothing of the kind in the novel: these two characters do not even meet, and Sergushin is not betrayed by anyone in particular.) In a major departure from the novel, Kot'ka escapes to Poland with Petliura's army and then comes back as a saboteur, essentially replacing the novel's Kozyr-Zirka. He is also the one trying to blow up, on Pecheritsa's orders, the factory in Mariupol. In turn, Pecheritsa receives his orders from a British sailor who has arrived in the town on the merchant ship Baltimore, on which Pecheritsa tries unsuccessfully to escape at the end. The screenwriters thus tied up all the loose ends scattered through the novel into a single Ukrainian nationalistic conspiracy sponsored by Great Britain.

If the scriptwriters produced a good Stalinist storyline and many visuals in the film connected it to contemporary cinematic portrayals of World War II, Restless Youth also contained the seeds of post-Stalinist cinema to come. This was the first film made by the young directors Aleksandr Alov and Vladimir Naumov, who would go on to make a major contribution to the cinema of the Thaw period. The studio assigned them to work on the film in August 1953 (TsDAMLM, 670/1/488, ark. 57). Pinpointing the traces of new elements in the film is difficult. The cinema historian Lubomyr Hoseiko, for example, names among them the portrayal of enemies as equals of the positive protagonists, although we now know that this resulted from the studio's ideological concerns reflecting the enduring Stalinist ideological climate in the aftermath of Stalin's death (Hoseiko 140-141). He also speaks of the crisp photography and effective use of lighting for psychological characterization, but these devices can also be seen in Stalin-era films made at Kyiv Film Studios, such as Ihor Savchenko's Bohdan Khmel'nyts'kyi (1941). The portrayal of Kot'ka Grigorenko in the final scenes as a broken, hysterical enemy sensing his end evokes parallels with Ivan Pyriev's Party Card (Partbilet, 1936), but it achieves greater psychological depth, especially in the powerful scene where Kot'ka smears his blood over his reflection in the mirror after agreeing to blow up the factory. ${ }^{12}$

\footnotetext{
12 See Shcherbenok 770. Clark observes perceptively that in Socialist Realist novels "villains commonly receive a fuller psychological portrayal than heroes do" (Clark 187).
} 
Yet, what truly connects Restless Youth to the future Thaw cinema is the emphasis on the young heroes" "sincerity." 13 The directors introduced the motif of Vasilii and Galia as young Komsomol activists being embarrassed about their love because romantic love and kissing are "bourgeois" things to them. Their low-key Komsomol romance, which is absent from the book, grants an aura of authenticity to their enthusiasm for labour and efforts to expose enemies. When Vasilii and Galia are finally ready to speak openly of their love for each other, they do so by addressing the Old Fortress. At the end of the film they yell words of love to the fortress walls in order to hear their echo; Alov and Naumov found an effective way to bring the fortress back into the film. Although the entire motif of an underground passage is absent from the final script, the fortress appears at the beginning: The film credits run against the background of its night-time silhouette, accompanied by music in a heroic key, as if the film were about the defense of the fortress. Later in the film, though, the Old Fortress begins to function as a prop more typical of post-Stalin cinema. It represents the childhood that the main protagonists have left behind, but to which they seek to relate in moments of important decisions. Of course, this metaphor should have been left for the viewer to discover instead of being spelled out rather crudely in the final scene, in which the young heroes speak across time to themselves as children still playing in the Old Fortress. However, even such an ending is better than the "finale in a high heroic tone" that the Ukrainian Republic's Ministry of Culture demanded (TsDAMLM, f. 670/1/488, ark. 14).

THE SERIAL

Whereas the fortress with its underground passages played an inconspicuous role in the 1954 movie, it occupied pride of place in the 1970s film adaptation. By the early 1970s the Soviet film industry had discovered the televised mini-series format, but used it differently from Western television. Instead of producing daily television programs aimed at entertaining audiences, the Soviets were essentially making lengthy films that could be split into a dozen or so one-hour serialized parts. Moreover, although they contained an element of adventure, Soviet serials usually covered patriotic historical topics, such as the Civil War or World War II. By far the most popular among them was Seventeen Moments of Spring (Semnadtsat' mgnovenii vesny, 1973), featuring a Soviet spy in wartime Nazi Germany, a twelve-episode espionage thriller that became a signature

13 On this concept, see Bulgakowa 437. 
phenomenon of late Soviet pop culture (Stites 170). As an indication of the genre's initial connection to youth adventure, however, director Tatiana Lioznova made this film at the Maxim Gorky Central Film Studio for Children and Youth in Moscow.

The early 1970s in Ukraine also marked the film industry's foray into the format of short television series. In 1973 director Mykola Mashchenko made a six-episode film at the Dovzhenko Film Studio based on the classic Socialist Realist novel, How the Steel Was Tempered (Kak zakalialas' stal') by Nikolai Ostrovskii. Film historians praised the powerful script by Alov and Naumov, as well as Mashchenko's poetic visuals connecting this film to the Ukrainian cinematic tradition (Hoseiko 260). In the same year the studio released the first three episodes of the new The Old Fortress. Kyivan filmmakers soon acquired somewhat of a reputation in the subgenre of revolutionary mini-series. If the first two films were set in Ukraine during and after the Civil War, thus justifying the choice of the Dovzhenko Studio, their next project had nothing to do with Ukraine. Yet the ten-episode Born of the Revolution (Rozhdennaia revoliutsiei, dir. Hryhorii Kokhan, 1974-76) probably surpassed in popularity any serials produced in the Ukrainian SSR during the Soviet period because of its subject matter: the early history of the Soviet criminal police.

The Old Fortress (1973-76) occupied a special niche among Soviet serials of the 1970s in that its first, longest, part in particular targeted preteens and teenagers. If the child heroes of the 1954 film appeared to be children playing in an episode of a Civil War movie, the new adaptation showed the Civil War through children's eyes. The film was a success and is remembered today because it narrated ideological conflicts in the language of children's adventure and at the same time encoded as politics some universal children's concerns and conflicts. Like some other early Soviet serials, The Old Fortress was filmed in three installments that were released separately. Instead of switching to the television-driven episode format, the filmmakers were essentially adapting the familiar, full-length movie format for the needs of television. In the case of The Old Fortress, there was also stylistic discontinuity among the various parts because after the first three Oleksandr Muratov replaced Mykhailo Bielikov as the director.

Unlike Restless Youth, which was described in the film credits as "based on" Beliaev's novel, the 1970 s version opened with the intertitle "Vladimir Beliaev, The Old Fortress," thus suggesting a faithful rendering of the novel's plot. In fact, the filmmakers took major liberties with the storyline, while preserving many details that made the novel such a success among several generations of Soviet children and young adults. Although Beliaev did not work on the script, he received a substantial copyright fee. As his correspondence with the scriptwriters suggests, however, he did not object 
to the revisions. ${ }^{14} \mathrm{~A}$ high-ranking studio official, executive editor Volodymyr Sosiura, Jr., teamed up with the film director Oleksandr Muratov to write the script. At the same time, Muratov did not direct the first part of the film, probably because he was uncomfortable taking on a children's movie. Instead, the studio invited a recent graduate of Moscow's Film Directing and Screenwriting Courses, Mykhailo Bielikov, who had worked on several children's films as a cameraman in the 1960s (TsDAMLM, 670/1/2442, ark. 17). ${ }^{15}$

The script for the first three episodes, known collectively as Part One, "Commissar Sergushin," continued the 1954 film's project to transform the novel's storyline in order to highlight the "party guidance" of the young protagonists. Sosiura and Muratov took the radical step of moving Sergushin's execution to the very end of the third episode. Vasilii first meets Sergushin when the latter is sick, but the commissar later recovers and leads the Bolshevik underground in the town from its base in the old Fortress. The task of locating the exit from the underground passage is now imbued with political meaning because this is how the children help the Bolshevik fighters escape the Ukrainian troops hot on their trail. For good measure, the authors had the other mentor figure in the novel, Lazarev the schoolteacher, join the underground after the Bolsheviks save him from execution. Vasilii spends considerable time interacting with Sergushin, and also saves the commissar during his first arrest by opening the car door to facilitate his escape. Later, he supplies the Bolshevik with newspapers and, together with his friends, gathers intelligence on Ukrainian patrol points at the fortress. When Sergushin is finally captured and executed, the boys mark his grave and, just like they do in the novel, take an oath of friendship and revenge.

Such a rendering of the storyline placed the Old Fortress with its underground passages in the center of the film's narrative-a wellcalculated move combining the attractive adventure story with that of revolutionary struggle. The director further amplified the importance of the fortress by including a general view of this structure at the start of every episode accompanied by a sound theme of "history" (rendered as the sound of wind blowing in a large, enclosed space). The script also reproduced the novel's encoding of children's games and school bullying as a symbolic

14 Beliaev received a copyright payment of 6,000 rubles (TsDAMLM, 670/1/2595, ark. 22), which technically bought him out completely, but the scriptwriters remained in touch with him. Part of his correspondence with the scriptwriters is in TsDAMLM, 670/1/2442, 2594, and 2596.

15 Bielikov went on to make a number of films for children and young adults and served as the head of Ukraine's Cinema Workers' Union from 1987 to 2005. 
replica of the Civil War that was raging in the adult world. The boys' complex relationships with their older classmates, who become the nucleus of the Ukrainian scout group, include various shades of envy, marginalization, and resistance to bullying; all recognizable to a pre-teen audience. These relationships progress from hide-and-seek games to fighting and, by the end of the film, to political denunciation of the Boy Scouts as "Petliurites." In order to spell out the connection to the adult political world, the screenwriters provide the Boy Scouts with a mentor, an officer of the Ukrainian army, Marko Hrzhybovs'kyi, who is portrayed as a brutal fanatic.

As soon as the filming started, however, a conflict emerged between the studio and the director. Ukrainian film historian Larysa Briukhovets'ka mentions Mykhailo Bielikov as one of the young Moscow-educated Ukrainian directors and cameramen who came to the Dovzhenko Studio in the 1960s with knowledge of world cinema trends and the desire to transform Ukrainian cinema (Briukovets'ka 12). Early on in the filming process, the studio officials sounded the alarm over the director's aesthetic solutions, including "rhythmic monotony and deliberate slowness" of action, as well as his "whimsical, intentionally strange actions and supposedly meaningful emotional accents" (TsDAMLM, 670/1/2594, ark. 14). This emphasis on contemplation and mood over action may reflect the influence of Michelangelo Antonioni, whose Il deserto rosso (1964) was known in the Soviet Union, or perhaps poetic cinema in general and in its Russian (Andrei Tarkovskii) and Ukrainian incarnations in particular. The studio functionaries also found troubling the director's modification of the "approved script," which apparently excluded some ideologically important confrontations in favor of either contemplative long shots or "exaggerated pantomime" in the portrayal of school lessons (TsDAMLM, 670/1/2594, ark. 17-18). (The latter may indicate the influence of another contemporary trend in world cinema, the surrealistic satire made popular by Federico Fellini's $81 / 2$.) The studio management issued Bielikov an official reprimand and forced him to reshoot and cut significant parts of the movie in order to restore the approved script. As a result, the final version of the second episode was only 1,364 meters long and, technically speaking, did not qualify as "full-length" but as a "short." The studio had to ask for a special dispensation from the All-Union Television's film production arm, Ekran, which had "commissioned" the series (TsDAMLM, 670/1/2594, ark. 22, 36).

Even after the extensive cuts and reshot footage, one can still see traces of poetic cinema, especially in the first episode. The long takes, which often feature silent depictions of panoramic landscapes, are reminiscent of Tarkovskii. Twice in the first episode Bielikov includes a long take of a frozen waterfall, with the camera moving slowly downwards then focusing 
on a horse waiting in the field below. If such visuals were intended to suggest the dream world of childhood, some adults in the film also come across as otherworldly dreamers, none of them more so than the boys' mentor, Lazarev, who is played by the prominent Russian theater actor Sergei Desnitskii, as an aloof intellectual searching for the deeper meaning of life. Presenting his vision to the studio, Bielikov claimed that he would not touch the storyline, and "everything that is new will be connected to [his] work with the actors" (TsDAMLM, 670/1/2442, ark. 30). Yet the film's very beginning shows how the familiar storyline could be presented visually to create a very different impression. For example, the ticking cuckoo clock serves as a leitmotif of the peaceful "home," as does the shot of Vasilii's father washing his feet in a basin (twice in the first episode). Both of these details are the director's inventions, which create the atmosphere of Vasilii's childhood. Even the arrival of the ailing Sergushin-a crisis that puts everyone in danger-does not make the characters move faster, something about which the studio complained. Another sequence at the beginning of the first episode is highly symbolic and reminiscent of Sergei Paradzhanov's film aesthetics. First, there is a long shot of a "naïve" photo on the wall showing a young peasant woman holding a baby next to a large stuffed bird on a stand. This is Vasilii's dead mother, although the viewer does not know this until much later. Next, Vasilii begins to fence with a wooden sword and shield while smiling strangely straight into the camera. Is it a game, a symbol of the war, or a cryptic comment on Vasilii's role in what is to come in the film? None of these shots change the storyline as such, yet they give the film a very different ambiance from the heroicromantic topos of the 1954 version.

In the portrayal of enemies, however, the possible influences of European surrealistic satire fit in nicely with the pre- and post-Stalinist Soviet cinematic tradition of carnivalesque buffoonery, suggesting the enemy's political impotence. A festive middle-class crowd of people holding icons and flags mistakes the car transporting the arrested Sergushin for Petliura's automobile and mobs it, thus unwittingly assisting the commissar's escape. The popular Russian film and theater actor Yevgenii Yevstigneev portrays Petliura (a silent role) in much the same way as Alexander Kerensky is traditionally depicted in Soviet movies: as a vain man concerned with his appearance and a servant of his alleged foreign masters. Burlesque, circus-like music accompanies his arrival. As he awaits the arrival of the Polish colonel, Petliura sits motionless, his eyes blinking nervously. Once the concert begins, the camera focuses on the large stone ring on Petliura's finger. Even as the others applaud the students, Petliura's hands remain still, only joining in the applause late and almost unwillingly. As if this were not enough, the studio officials suggested bringing back a 
more primitive form of the banded anteater motif from the previous adaptation by including a close-up of the school warden, who replaces the picture of the animal with one of Petliura (TsDAMLM, 670/1/2594, ark. 27, 43).

If Petliura is aloof and distant, the filmmakers develop the character of the Ukrainian army captain Marko Hrzhybovs'kyi, the elder son of a local sausage-maker, into the principal enemy on the ground. Marko first appears on screen wearing red hussar trousers, in what is probably a cinematic reference to Popandopulo from Andrei Tutyshkin's Wedding in Malinovka (Svad'ba v Malinovke, 1967). Indeed, he shares Popandopulo's traits of a weak, comedic enemy and unimpressive physical appearance, and he too is beaten up by various characters, including children. ${ }^{16}$ At the same time, however, there is a sadistic side to Marko, who seems to enjoy flogging his younger brother and burning down houses. He also participates in searches and commands the firing squad during an execution. Significantly, Marko's surname in the film as well as in the novel sounds more Polish than Ukrainian, thus suggesting that he is allied with the occupiers because he is not Ukrainian (as opposed to being a Ukrainian patriot). Or, perhaps, the name implies that Ukrainian nationalists are not true Ukrainians.

If Ukrainian filmmakers understood their duty as a responsibility to engage the issue of Ukrainian nationalism head on, their Moscow overseers worried about how Russian audiences would interpret the film. The officials at Ekran demanded some very telling, last-minute changes to the first three episodes, including cutting the scene of the bourgeois public presenting Petliura's troops with bread and salt, and excising the entire line of what happened to the banner that the boys captured from the Boy Scouts (TsDAMLM, 670/1/2594, ark. 30). The blue-and-yellow Ukrainian national flag plays an ambiguous role in the book. The main heroes first hide their trophy in the forest; then Yuzik smuggles it home by wrapping it around his body under his clothes. Finally, Yuzik's mother makes him a blue silk shirt out of one half of the flag, and he gives the other half to Vasilii as a great treasure when he moves to another city. Vasilii in turn leaves it to Pet'ka Maremukha when his turn comes to leave town. Whatever symbolism Beliaev had originally intended for this story, to Moscow's television officials in 1973 the visual references to the archetypal motif of Soviet war films, that of "saving the Red banner," seemed too obvious.

They also demanded that the scene with the Shevchenko poem be clarified for Russian-speaking audiences elsewhere in the Soviet Union, "keeping in mind that not everyone will understand poetry in Ukrainian"

16 On the character of Popandopulo in Wedding in Malinovka, see Pressitch. 
(TsDAMLM, 670/1/2594, ark. 30). What the officials meant was probably not so much the meaning of the verses as the relevance of the poem itself to the Soviet television audience of children and young adults. Whereas Polish lords and priests remained enemies of the day for Beliaev in the late 1930s and the Ukrainian-Polish friendship was something to be achieved in the socialist future, the screenwriters of the late Soviet period found it easier to connect the Polish officer's hatred of Shevchenko to the Bolshevik revolution. As a result, in the film a stanza from the poem appears on Bolshevik leaflets distributed in the town, and the Polish officer at the concert calls it "Bolshevik propaganda." These words appear in the novel as a metaphor for Shevchenko's poetry, making him an "eternal enemy of the Polish church and the Vatican" (Beliaev, Staraia krepost' 32-33). But in the film they actually refer to the very real leaflets distributed by the Bolshevik underground.

The Dovzhenko Studio used a different director for the next two episodes that were bundled together under the subtitle "A Haunted House." Oleksandr Muratov, who from the very beginning co-supervised the project with Sosiura as screenwriter, took over the directing from Bielikov, a move that resulted in a very different visual style. Episodes Four and Five come across as much more realistic, and they are devoid of the whimsical elements that indicated a connection to poetic cinema. The scriptwriters also raised the age of the main characters from fourteen to sixteen, probably for a combination of reasons: the difficulty of working with child actors, a more appropriate age for romance, and the setting of the next two series shifting from the mid-1920s to the more glorious period of the First Five-Year Plan. As a result, the film begins with a shot of the bare-chested, blue-eyed Vasilii (Vladimir Leletko), who looks very much like a 1970 s Western pop star even as he is painting his dovecote. Indeed, some of the plot elements now looked too childish for the main protagonists. The novel did not allow much leeway for the development of Vasilii's romance with the equally gorgeous Galia Kushnir (Iulia Iakub), both because of their age and because they would not get married in the sequel. In addition, the other occupations and interests of the main protagonists now seemed somewhat immature. The studio made a point of demanding that the entire line of the "invisible bell" be redone, so as "not to appear naïve" (TsDAMLM, $670 / 1 / 2595$, ark. 6). If in the novel the Polish yard keeper rings the bell hidden in the chimney in order to scare the Red cadets with the ghosts of long-dead nuns, in the film it is Kot'ka Grigorenko who rings it to give the signal for the Ukrainian nationalists to attack.

Continuity in the portrayal of enemies is established not just through Kot'ka. The "Petliurite gang" invading from across the border includes the familiar faces of Captain Marko Hrzhybovs'kyi and another Ukrainian 
officer from the previous series. However, they are all eliminated in these two episodes. Vasilii, who is sleeping in a haystack, shoots Marko pointblank when the nationalists attempt to burn the hay. The rest of the Petliurites hide in the cemetery-a symbol of their affiliation with the past-awaiting the bell signal, but the Bolshevik machine-gunner is going to spare none of them. The character of Pecheritsa underwent perhaps the most interesting transformation. There is no mention in the film of his involvement in the Ukrainization campaign or his dismissal of Russianspeaking instructors, but he is still the ringleader of the nationalist underground. The filmmakers establish his Ukrainian identity in a number of subtle ways. Pecheritsa speaks Russian with an "authentic" Galician accent, because the director cast the young Lviv theater actor Bohdan Kozak. (In the 1954 adaptation, the great dramatic actor Yuri Lavrov was clearly miscast as Pecheritsa because he spoke and behaved like an upperclass Russian from tsarist times.) Pecheritsa and his wife wear elaborately embroidered Ukrainian shirts compared to the more modest ones worn by other, positive, Ukrainian characters, such as Vasilii's father and Lazarev. Finally, Pecheritsia is shown conducting, with ecstatic fervor, the choir singing Shevchenko's "Testament" ("Zapovit”).

The last scene merits closer attention because of its ideological and visual interpretations in the film. In the novel, Pecheritsa's student choir sings various Ukrainian songs, including the Galician Sich Riflemen song, which sounds alien to Vasilii, who later remembers hearing it when Petliura is in power. The cultural reference in the film is simplified in order to place the struggle over Ukrainian identity front and center. The choir thus sings the most famous, anthem-like song to the words of the "father of the nation" (Shevchenko). Yet Pecheritsa, who is conducting with his eyes closed, stops the choir for a break just before the lines, "And in the great family, the family free and new / Do not forget to remember me with a good, quiet word." This is significant because in the Soviet period these lines were interpreted in the school curriculum as a reference to the socialist future that the Bolsheviks had turned into reality. Therefore, in the film Pecheritsa does not want to hear these words, which Soviet Ukrainians now claimed for themselves. Once again the filmmakers use Taras Shevchenko, the principal Ukrainian cultural icon, to establish the nationalists' "faulty" Ukrainian identity. Moreover, the director also wanted to encode visually Pecheritsa's difference from the young people singing in his choir. In the book, all of them wear Ukrainian embroidered shirts, but in the film this would suggest unity rather than difference. What we see instead is Pecheritsa in an embroidered shirt conducting a choir of young women wearing red kerchiefs and young men in quasi-military tunics; in other 
words, typical Soviet Komsomol members of the 1920s, whose Ukrainianness is indicated only by the song they are singing.

The production notes reveal that the studio officials were concerned about the portrayal of Ukrainian identity in this Russian-language television series. The director had originally wanted to use a mixture of Russian and Ukrainian, as well as occasional dialecticisms, to indicate the film's Ukrainian setting (TsDAMLM, 670/1/2442, ark. 28). In the final version, however, it is only "Petliurite bandits" and female peasants who speak Ukrainian. The latter also sing two Ukrainian songs that sound like recordings made by a professional choir. In contrast, all the main characters speak Russian, even though their names and backgrounds suggest that they are ethnic Ukrainians. Together with Vasilii, the cadets sing a Russianlanguage Bolshevik Civil War song with the refrain, "The guns rumbled, rumbled / Our machine-gun spluttered / The bandits were retreating / We were advancing."

Perhaps the greatest contrast with the 1954 version lies in the portrayal of the Komsomol activist Kolomeets, who is shown as a vulnerable individual on the verge of a nervous breakdown. Some characters mention that his "nerves are no good," which can be explained by the star-shaped scars on his back, a sign that he was tortured by the enemy during the Civil War. In a highly unusual move for a positive character in late Soviet Ukrainian cinema, Kolomeets also speaks of his experience of starving during the 1921 famine. In general, the desire to preserve all the novel's positive adult characters did not allow the filmmakers enough creative leeway to develop even a single one into a true mentor for the youngsters. As a counterweight to Pecheritsa, Vasilii's father and Lazarev also wear Ukrainian embroidered shirts, but both come across as aloof, episodic characters. There is no clear replacement for Commissar Sergushin, even though the cadets' school in the film is named after him. The school's director, Polevoi, and its Komsomol leader, Marushchak, never really develop the same rapport with Vasilii as the troubled Kolomeets.

In a major departure from the novel, Ukrainian nationalist saboteurs do not appear in the last two series, which are paired under the title "A City by the Sea" and set in an unspecified city on the Azov Sea. The filmmakers extended the passage of time from when the narrative stopped in "A Haunted House" to seven years, which allowed them to cast professional actors or theater students. No less importantly, this move shifted the action to 1930, the period of the First Five-Year Plan, thus making industrial production the central topic-much like it was in Brezhnev's time. Unlike in the Stalin period, in the 1970s the official party line on history did not explain the industrial accidents of the First Five-Year Plan by enemy sabotage. When the script went through two rounds of discussion at the 
studio, the managers and directors on the Artistic Council unanimously recommended "excluding the motif of intentional sabotage by foreign agents" (TsDAMLM, 670/1/2595, ark. 20; 670/1/2596, ark. 4). Instead, they suggested blaming the boiler explosion on workers' negligence connected to drinking on the job. As the Artistic Council opined, such a storyline would be "more topical for educating contemporary youth" (TsDAMLM, 670/1/2596, ark. 5). In this kind of editing, one can also see an attempt to avoid references to the Great Terror with its paranoid search for "wreckers." The arrival of the investigating OGPU officer at the factory was reshot at the last moment, and new dialogue was recorded in order to make him appear less threatening, as well as to remove any impression that Vasilii is among his initial suspects (TsDAMLM, 670/1/2595, ark. 1). Somewhat incongruously, the explosion scene is accompanied by the musical theme of the Petliurite invasion from the previous series, tantalizing the viewer with the expectation of an enemy plot.

In other respects, the last two series represent a curious mixture of a Soviet industrial movie and a young-adult romance film. Vasilii's relationship with his new love interest, Lika, features declarations of love, kissing, jealousy, and the obligatory ideological re-education of the "bourgeois" Lika. The director Oleksandr Muratov ran afoul of the studio officials by developing the young lovers' game of calling each other Lieutenant Glahn and Edvarda (the doomed lovers in Knut Hamsun's novel Pan) into a series of dreamy inserts shot on an imaginary "island" and featuring late nineteenth-century costumes. ${ }^{17}$ Substantial cuts were made eventually to these "dreams," which are also ascribed more to Lika, because the studio management felt that "she, rather than Vasilii, is infected with false romantic ideas" (TsDAMLM, 670/1/2595, ark. 1). However, Vasilii eventually rejects the "fallen" Lika in favour of what was always central to him: the search for a new formula for cast iron and the production of mechanical reapers for Kolomeets's collective farm. The screenwriters boldly transformed the novel's plot to make him look like a typical hero of the late Soviet industrial film genre, a young graduate working to improve production methods who is eventually promoted to shop floor manager. At the end of the film, the main hero's return to Kamianets-Podilsky appears artificial, simply an opening for meaningless flashbacks that fail to connect

\footnotetext{
17 Hamsun is referred to in the film only as "a Scandinavian writer," likely because of his ostracism in the postwar Soviet Union, which stemmed from the writer's proNazi sympathies. No books by Hamsun were published in the USSR between 1935 and 1970; afterwards, they appeared only rarely and with introductions condemning his political views. See Budur chap. 20.
} 
the last two episodes to the early series' spirit of adventure and overcoming the enemy.

$$
* * *
$$

The Old Fortress in all its literary and cinematic incarnations played a prominent role in Soviet negative mythmaking about the Ukrainian Revolution and non-Soviet Ukrainian identity more generally. It helped instill in Soviet mass culture the image of an evil Ukrainian nationalist, a Petliurite, which eventually evolved into that of a Banderite-a stereotype that is still very present in today's Russia. Tellingly, The Old Fortress went through at least three editions in post-communist Russia, with a mass edition issued in 2011 by the country's second-largest publisher, Eksmo. Beliaev's novel is also widely available for free downloading from the Internet, including as an audiobook. It often appears on lists of recommended, extra-curricular reading for Russian schoolchildren, including those posted by schools ("Rekomendovannyi spisok...").

A closer look at the novels and the films reveals that the portrayal of "Petliurites" and Soviet Ukrainians evolved considerably between the late 1930 s and the 1970s, and not just in terms of the replacement of strong villains with weaker ones, a decision that also generated more ambiguous positive protagonists. In postwar film adaptations of Beliaev's trilogy, the filmmakers tried to balance the changing ideological expectations with the adventure element that had made the novel such a prodigious bestseller. While both films developed the theme of "party guidance" for youngsters, there was also a significant difference between their depiction of the Ukrainian Revolution and its aftermath. The main focus of the 1954 version was on presenting the Ukrainian nationalists as a powerful enemy supported by the West, who continue their sabotage well into the Soviet period. In the 1970s serial, the villains are weaker, even caricatured. The emphasis is more on the "positive" Soviet Ukrainian identity, for which the filmmakers recruited the national bard of Ukraine, Taras Shevchenko, to serve as a main symbol. Among the adults in the film, however, Soviet Ukrainian identity comes across as curiously Russianized in the early episodes and becomes irrelevant in the latter ones. While the 1954 version excluded many adventure elements, possibly on the assumption that viewers would be familiar with the story anyway and that providing a forceful ideological interpretation would be more important, the 1970s adaptation attempted to recover them for the new generation of young Soviet adults. If the 1954 film's greatest appeal for audiences was the topos of Komsomol "sincerity" foreshadowing the cinema of the Thaw, the 1970s series were most successful precisely because they engaged younger 
audiences with adventures that replicated the revolution symbolically and encoded as political such universal childhood conflicts as schoolyard bullying. Significantly, the inclusion or exclusion of the Old Fortress itself usually served as a reliable predictor of the film's ability to engage the world of childhood in the process of creating a historical-revolutionary narrative for Soviet youth.

\section{Works Cited}

Abramson, Henry. A Prayer for the Government: Jews and Ukrainians in Revolutionary Times, 1917-1920. Cambridge, Mass.: Harvard Ukrainian Research Institute, 1999. Print.

Beliaev, Vladimir. "Nachalo." Ia dumal, chuvstvoval, ia zhil: Vospominaniia o S. Ia. Marshake. Eds. B. E. Galanov, I. S. Marshak, and Z. S. Papernyi. Moscow: Sovetskii pisatel', 1971. 162-72. Print.

---. Staraia krepost': trilogiia. Kyiv: Radians'ka shkola, 1984. Print.

Briukovets'ka, Larysa. "On the Ukrainian Cinematic Tradition, the Dovzhenko Film Studio, and Ivan Mykolaichuk," Canadian Slavonic Papers 56.1-2 (March-June 2014): 7-16. Print.

Budur, Natalia. Gamsun: Misteriia zhizni. Moscow: Molodaia gvardiia, 2008. Print.

Bulgakowa, Oksana. "Cine-Weathers: Soviet Thaw Cinema in the International Context." The Thaw: Soviet Society and Culture during the 1950s and 1960s. Eds. Denis Kozlov and Eleonory Gilburd. Toronto: University of Toronto Press, 2013. 436-81. Print.

Clark, Katerina. The Soviet Novel: History as Ritual. 3rd ed. Bloomington: Indiana UP, 2000. Print.

Fateev, A. V. Stalinizm i detskaia literatura v politike nomenklatury SSSR, 1930-e1950-e gg. Moscow: Maks-press, 2007. Print.

First, Joshua. Ukrainian Cinema: Belonging and Identity during the Soviet Thaw. London: I. B. Tauris, 2014. Print.

Fürst, Julianne. Stalin's Last Generation: Soviet Post-War Youth and the Emergence of Mature Socialism. Oxford: Oxford UP, 2010. Print.

Galias, Aleksandr. "Zagadka 'Staroi kreposti'," Porto-franko 19 March 2010. Web. 1 Nov. 2015. <http://porto-fr.odessa.ua/index.php?art_num=art020\&year= 2010\&nnumb $=10>$.

Hoseiko [Hosejko], Liubomyr. Istoriia ukrains'koho kinematohrafa, 1896-1995. Trans. Stanislav Dovhaniuk and Liubomyr Hoseiko. Kyiv: KINO-KOLO, 2005. Print.

Hrekov, Oleksandr. "Spohady viis'kovoho ministra UNR henerala Hrekova." $Z$ arkhiviv VUChK-GPU-NKVD-KGB, 1-2 (2004): 121-209. Print.

Iurkova, Halyna, et al. Kam"ianets'-ostannia stolytsia UNR: Putivnyk. KamianetsPodilskyi: Medobory, 2011. Print.

Kaganovsky, Lilya. How the Soviet Man Was Unmade: Cultural Fantasy and Male Subjectivity under Stalin. Pittsburgh: University of Pittsburgh Press, 2008. Print. 
Kalynchuk, Dmytro. "Khto zibrav dlia Petliury 'petliurivtsiv'? Otaman i ioho armiia." Istorychna Pravda 28 September 2012. Web. 1 Nov. 2015. <http:// www.istpravda.com.ua/articles/2012/09/28/95309/>.

Kappeler, Andreas. "Mazepintsy, Malorossy, Khokhly: Ukrainians in the Ethnic Hierarchy of the Russian Empire." Culture, Nation, and Identity: The UkrainianRussian Encounter (1600-1945). Eds. Andreas Kappeler, Zenon Kohut, Frank Sysyn, and Mark von Hagen. Edmonton: Canadian Institute for Ukrainian Studies Press, 2003. 162-81. Print.

Kelly, Catriona. Children's World: Growing Up in Russia, 1890-1991. New Haven, Conn: Yale UP, 2008. Print.

"Novizhen, Iankel' Abramovych." Natsional'nyi bank represovanykh. Web. 1 Nov. 2015. <http://www.reabit.org.ua/nbr/?ID=154894>.

Pressitch, Olga. "Civil War as Musical Comedy: The Representation of the Ukrainian Revolution in the Soviet Film Wedding in Malinovka (1967)." Australian and New Zealand Journal of European Studies 5.2 (2013): 83-91. Print.

Razumnevich, V. Vladimir Beliaev: ocherk tvorchestva. Moscow: Detskaia literatura, 1983. Print.

"Rekomendovannyi spisok literatury dlia vashego rebenka." Detstvo.info. Web. 1 Nov. 2015. <http://www.detstvo.info/informacija/booklist.html>.

Rubl'ov, Oleksandr. Zakhidnoukrains'ka intelihentsiia u zahal'nonatsional'nykh politychnykh ta kul'turnykh protsesakh (1914-1939). Kyiv: Instytut istorii Ukrainy NAN Ukrainy, 2004. Print.

Shcherbenok, Andrei. "The Enemy, the Communist, and Ideological Closure in Soviet Cinema on the Eve of the Great Terror (The Peasants and The Party Card)." Kritika 10.4 (Fall 2009): 753-77. Print.

“Spisok knig dlia chteniia. Budushchii 7 klass, 16 June 2015.” Shkola No. 38, g. Kaliningrad. Web. 1 Nov. 2015. <http://folks.school38.org/index.php/ blogs/42-7-g-2015/1758-spisok-knig-dlya-chteniya-budushhij-7-klass>.

Stalin, I. V. "Ob antileninskikh oshibkakh i natsionalisticheskikh izvrashcheniiakh $\mathrm{v}$ kinopovesti Dovzhenko 'Ukraina v ogne'." Kremlevskii kinoteatr: Kul'tura i vlast' ot Stalina do Gorbacheva, 1928-1953. Ed. K. Anderson, et al. Moscow: ROSSPEN, 2005. 693-704. Print.

---. "Pis'mo L. M. Kaganovichu (11 avgusta 1932 g.)," in Stalin i Kaganovich: Perepiska 1931-1936 gg., ed. O. V. Khlevniuk et al. Moscow: ROSSPEN, 2001. 273-75. Print.

Stites, Richard. Russian Popular Culture: Entertainment and Society since 1900. New York: Cambridge UP, 1992. Print.

Taniuk, Les'. Liniia zhyttia (z shchodennykiv). 2 vols. Kharkiv: Folio, 2004. Print.

Tinchenko [Tynchenko], Iaroslav. "Belaia gvardiia" Mikhaila Bulgakova. Kyiv and Lviv: Missioner, 1997. Print.

Trymbach, Serhii. Oleksandr Dovzhenko: Zahybel bohiv. Identyfikatsiia avtora $v$ natsionalnomu chaso-prostori. Vinnytsia: Hlobus-Pres, 2007. Print.

Tynchenko, Iaroslav. Ofitsers'kyi korpus Armiï Ukrains'koi Narodnoi Respubliky (1917-1921). Kyiv: Tempora, 2007. 2 vols. Print. 